\title{
Female Post-Revolutionary Voices - Literature and Art without Men
}

\begin{abstract}
After the Islamic Revolution of 1979, Iranian women writers with their feminist issues successfully stepped into mainstream literary discourse, focusing on topics previously omitted, emphasising socio-cultural gender issues and contributing to the development of specific attitudes and values among readers. The article comments on the post-Revolutionary women's criticism in Iran expressed through literature and art, that has been aimed at not only the political establishment, but also the wider patriarchal cultural patterns. The example analysed in the text is the novel Women without Men by Shahrnush Parsipur - an important contribution to Iranian post-Revolutionary literature that helped to shape feminist discourse and inspired future generations of writers and other artists, contributing to the fact that women's issues have gained a new meaning in contemporary Iran. On the example of Women without Men, as well as the works of Shirin Neshat - a widely recognised Iranian visual artist - inspired by the novel, the article shows how Iranian female artists have engaged in the struggle for women's issues and are advocates of change in the Iranian society shaped by the male-dominated culture.
\end{abstract}

Keywords: Iranian contemporary literature, Iranian novel, feminist art

In the last decades of the $20^{\text {th }}$ century Iranian women - actively involved in the Islamic Revolution of 1979 - have become aware of their political potential and have engaged in an active struggle for their rights. Over time, more religious Muslim women also joined such activities, putting forward a more egalitarian interpretation of Islam as a religion that in the contemporary period may treat both sexes with greater equality. ${ }^{1}$ On this basis, along with post-Revolutionary socio-political changes, a kind of feminism arose - not only as an ideology opposite to the new regime's gender policy, but also as a new literary movement. ${ }^{2}$ Literature created by Iranian women became sensitive to-

${ }^{1}$ Cf. N.R. Keddie, Modern Iran: Roots and Results of Revolution, New Haven 2006, pp. 292-297.

${ }^{2}$ K. Talattof, The Politics of Writing in Iran: A History of Modern Persian Literature, Syracuse 2000, pp. 171-172. 
wards women's issues and gender relations in their society. Their narratives articulate protests against sexual oppression and reflect women's struggle for identity, making public their personal experiences. ${ }^{3}$

Post-Revolutionary women's criticism has been aimed at not only the political establishment, but also the wider patriarchal cultural patterns, concerning both men who impose restrictions on women's rights, as well as those who passively accept them. Feminist themes, symbolism and terminology have appeared both in the works of the post-Revolutionary generation of writers, as well as those writing for a long time, such as Simin Behbahani or Simin Daneshvar. Not only has the number of women writers increased, but also the amount of women readers, because Iranian women - as exemplary mothers and wives shut indoors by the ideology of the Islamic Republic of Iran - began to read more, creating new space for literature written by women for women. ${ }^{4}$ As noted by Lewis and Yazdanfar, the post-Revolutionary decade of limitations put on women's presence in the public space ironically made their voices much more audible via stories and novels. ${ }^{5}$

\section{Women without Men - A Novel on Women's Issues and Virginity in Iranian Society}

An important contribution to Iranian post-Revolutionary feminist literature has been made by Shahrnush Parsipur (b. 1946), one of the most famous contemporary Iranian female writers, who - after her years of struggle with the reality of the Islamic Republic - is now living and working in exile. Probably her most famous novel is Tuba and the Meaning of the Night (Tuba va ma'nay-e shab, 1989) ${ }^{6}$ a multi-layered novel, which can be "read as a kind of manifesto for a 'natural' feminism, as well as a record of the path of its protagonist's spiritual development in the search for self-awareness and understanding of the mysteries of existence". 7 However, the novel of interest to me here is Women without Men (Zanan bedun-e mardan), that was introduced to me by professor Anna Krasnowolska when I was a student. As I spent a great deal of time with this book, analysing and translating its chapters to Polish for my MA dissertation, it became for me one of the most important novels I have ever read and I often refer to it during my classes and encourage my students to read it.

The novel Women without Men is set in 1953 and describes events that took place during the crisis in Iran with its peak in August. In a coup d'état aided by the CIA the Iranian government led by Prime Minister Mohammad Mosaddeq,

3 Idem, Iranian Women's Literature: From Pre-Revolutionary Social Discourse to Post-Revolutionary Feminism, "International Journal of Middle East Studies" 1997, no. 29(4), p. 531.

4 Ibidem, pp. 549-552.

5 F. Lewis, F. Yazdanfar, Introduction: Iranian Women, the Short Story and the Revolution 1979, [in:] In a Voice of Their Own: A Collection of Stories by Iranian Women Written since the Revolution of 1979, eds. F. Lewis, F. Yazdanfar, Costa Mesa 1996, p. xxiii.

${ }^{6}$ Cf. K. Talattof, Iranian Women 's..., pp. 544-545.

7 A. Krasnowolska, Posłowie, [in:] S. Parsipur, Tuba i znaczenie nocy, Kraków 2012, p. 434. 
known for his policy of nationalising the Iranian oil industry that was unfavourable for the West, was overthrown. The Parsipur's book was published in Iran only once, after the death of ayatollah Ruhollah Khomeyni in 1989, and was very soon removed from bookstores following a decision from the authorities after five thousand copies had been sold during the first week. This caused not only problems for Parsipur to publish her works, but also led her - the author who dared to challenge the taboo of virginity - to imprisonment.

The novel Women without Men, although so strictly inscribed in a very specific moment of modern Iranian history, can be considered an allegory of the situation in post-Revolutionary Iran. Parspiur revealed the gender relations prevailing in Iranian society, socio-cultural oppression of women, as well as their desires, dreams and aspirations in the context of social roles they are forced to adopt by the Islam-dominated society. Parsipur, as well as other Iranian writers - forced to undergo political pressure and censorship that have left little space for free debate - often uses history as a mean of disclosing current problems. As Mobasser points out, contemporary Iranian literature is "very political and socially conscious - even (or maybe especially) in its silence". ${ }^{8}$

The short novel Women without Men is actually a collection of fifteen stories, interconnected by a common plot that connects the lives of five women in a magical garden in Karaj. It is not a simple narration, but a dialogical story, representing diverse points of view and attitudes. The characters are of different ages and from different social classes, speak differently and choose a variety of paths in their lives, none of which is evaluated here as better or worse - no matter whether a woman finally returns to society or ends up in a mythical, unreal world. One can say that the novel is a debate of several voices on femininity and the problems of women in Iranian society, and the characters taking part in it are designed to show the multidimensionality of these issues. ${ }^{9}$

Parsipur in Women without Men shows what it means to be an Iranian woman. Her focus is to present the huge role that virginity plays in women's lives and "how the normative sexual morality surrounding female virginity shapes the feelings, aspirations, and internal conflicts of women". ${ }^{10}$ The protagonists are prisoners of their virginity - one of them, for example, surrendered her life to the constant fear of tearing her hymen, even unintentionally, and as a girl used to avoid, for instance, climbing trees and other activities. Having realised the unnecessary pressure under which she had lived since her childhood, she committed suicide. Another character in the novel is a prostitute raised from childhood in a brothel, where she began her sexual life. She depicts the fate of women who are unmarried, but no longer virgins - in Iranian society sentenced to loneliness, to work as prostitutes or, at best, a temporary marriage, commonly called siqe. A similar fate befell another character - in her case, her loss of virginity was by force, due to

${ }^{8}$ N. Mobasser, Introduction, [in:] S. Rahbaran, Iranian Writers Uncensored: Freedom, Democracy, and the Word in Contemporary Iran, Champaign 2012, p. xxii.

9 K. Sheibani, Without Men: Parsipur's Polyphonic Novel, Iranian.com, http://iranian.com/ Books/2003/September/KS/index.html (access: 12.12.2016).

10 K. Talattof, Iranian Women's..., p. 545. 
rape, but she is aware that a women in her situation has lost her good name forever. Iranian society does not give her the chance to recoup her reputation - losing virginity, a girl forgoes the chance to organize her life as an exemplary wife and mother. Iranian society "does not condemn the boy who lost his virginity, even if he maintains a series of long-term relationships with women, but a girl who lost her virginity is heavily punished as a person who endangers the dignity and honor of her family". ${ }^{11}$

According to Islamic teachings, sexual desires are a natural human need that to maintain mental and physical health - it is necessary to satisfy, as well as other needs, such as hunger or thirst. ${ }^{12}$ Physical pleasures are meant to give Muslims a foretaste of Paradise. However, female sexuality could potentially cause the destruction of the social order established by God, so women require much tighter control than men. ${ }^{13}$ To protect the male lineage, female sexuality must be limited within a strict framework - around this issue revolve the key concepts for this culture of "the virginity of unmarried girls, the fidelity of married women, and the sexual abstinence of widows and divorcees". ${ }^{14}$ Even a one-time sexual adventure is associated with general condemnation: "no woman can afford to gamble with her 'symbolic capital' without running the risk of tarnishing her reputation and greatly diminishing her chances for a desirable permanent marriage". ${ }^{15}$ So this uncompromising view leads to hypocrisy - women pretend to be virgins, restoring their virginity by procedures such as the reconstruction of the hymen, so that the wedding night would not reveal the truth about their past. Also in the novel by Parsipur there is a character who gets her newly married husband drunk to make him not realize that she is no longer a virgin. Today, modern hymenoplasty is thriving in Iran, along with the rising age of first marriages and a growing - especially in cities - number of people involved in premarital or extramarital sexual relations, facilitated by dating in cyberspace. The opinion of feminists on this issue are divided, ranging from underlining that such practices reinforce existing power relations to noticing that such behaviour contributes to the weakening of the importance of virginity in culture. ${ }^{16}$

In her novel Parsipur shows how Iranian cultural norms surrounding sexuality justify violence against women and excuse the aggressor. ${ }^{17}$ If by chance an unmarried girls gets pregnant, she would dishonour her family and might be not only beaten, but even the killed to purge the shame. Moreover, in a society that so clearly has confined a woman to the restrictions associated with her gender affiliation, rape is treated as "a powerful tool of revenge and intimidation". ${ }^{18}$ Two girls

11 Doniya-ye zan: Dar goft-o-gu ba allame-ye Seyyed Mohammad Hoseyn Fazlallah, Tehran $1383 / 2004$, p. 381.

12 Ibidem, p. 365.

13 M. Ruthven, Islam: A Very Short Introduction, New York 2012, pp. 111-112.

14 F. Milani, Gender Relations: i. In Modern Persia, [in:] Encyclopaedia Iranica, vol. 10, ed. E. Yarshater, New York 2001, p. 405.

15 S. Haeri, Law of Desire: Temporary Marriage in Shi'i Iran, Syracuse 2014, p. 201.

16 J. Afary, Sexual Politics in Modern Iran, Cambridge, UK, New York 2009, p. 337-338.

17 K. Talattof, The Politics..., p. 147.

18 F. Milani, Gender Relations..., p. 405. 
in the novel by Parsipur fell victim at the hands of truck drivers while they wanted to resist their families limiting their freedom and left for a journey, abandoning the realm of reality traditionally belonging to women. In the eyes of Iranian society they were at fault for the harm that befell them, because as far as the mobility of men is a positive value, the mobility of women is traditionally connected with sexual promiscuity and prostitution. ${ }^{19}$ However, the novel gives women hope - in contrast to what happens in a real life, male aggressors are punished by some kind of force majeure, when a few kilometres away they have a fatal accident, which can be interpreted as a partial compensation for the victims of injustice.

\section{Women without Men - A Magical Novel on Women's Utopia}

The same as history, the magical realism characteristic for Parsipur's Women without Men also serves the purpose of disclosing issues that cannot be freely expressed. The roots of the magical themes present in the novel can be traced to Persian folklore and mythology, as well as the works of contemporary Iranian writers earlier than Parsipur (such as Sadeq Hedayat and Sadeq Chubak). The spread of the fashion for magical realism among the post-Revolutionary Iranian writers was influenced at the beginning of the 1980s by the works of Gabriel García Márquez and Salman Rushdie. ${ }^{20}$ It attracted such female writers as Shahrnush Parsipur or Moniru Ravanipur because through this style they could best express women's issues that could not be mentioned directly. ${ }^{21}$

Let me comment now on a symbolical layer of Women without Men. Its central symbol is a garden, where the fate of all five characters intertwines. A Persian term baq, most often translated as a "garden", means a closed area, used for permanent vegetation (trees and shrubs) and in fact can relate to fruit orchards, vineyards and olive groves, but not to places growing vegetables. Due to Iran's dry climate, typically such gardens are located near a source of water, like a stream, a spring, a well or an irrigation canal. Plots of land of different size are usually surrounded by high walls of clay or - in mountainous areas - are arranged in the form of terraces. ${ }^{22}$ Persian kings and noblemen had for their own usage this type of space that reflected a paradise garden, like the vineyards of the Achaemenids (ca. 550-330 BC) described by the Greeks. Some of these places have survived in Iran until now - for example Baq-e Shah in Tehran, Baq-e Hasht Behesht in Isfahan or Baq-e Fin in Kashan. ${ }^{23}$ Today, many residents of Tehran have their own separate gardens, to have a place to spend time in the summer or organize family meetings or celebrations - for example, the Iranian New Year (Nouruz), celebrated along with the awakening of nature in spring. As a poetic symbol in

${ }^{19}$ Cf. ibidem.

${ }^{20}$ F. Lewis, F. Yazdanfar, op. cit., pp. xxi-xxii.

21 K. Talattof, The Politics..., pp. 155-156.

${ }^{22}$ Cf. M. Bazin, Baḡ: ii. Gneral, [in:] Encyclopaedia Iranica, vol. 3, ed. E. Yarshater, London-New York 1989, p. 393-395.

23 M.J. Yahaqqi, Farhang-e asatir va dastan-vareha dar adabiyat-e farsi, Tehran 1386/2007, p. 197. 
Persian literature, a garden means beauty, order and the link between man and nature. Since the reign of the Qaznavid dynasty (962-1186) poets have described gardens in a certain conventional manner, usually focusing on the vegetation and especially praising their charms in the spring season, when they became the image of beauty. ${ }^{24}$ Parsipur in her novel Women Without Men also repeats this manner, presenting the garden during the spring, when after pruning and gardening it finally blooms in all its glory - finally "the garden was a garden". ${ }^{25}$

From illustrating earthly paradise in Persian literature, the garden has expanded its meaning and became a symbol of Paradise, also based on the descriptions borrowed from the Koran. The garden of Paradise is a place where "the chaos and danger of nature outside are changed to order and security". ${ }^{26}$ The garden in the novel Women Without Men is such an ideal space, separated from the surrounding world, a safe haven for women escaping from the reality where they are subject to male domination. In its spatial structure, the garden meets the requirements of a sacred space, recalling shrines surrounded by fences, walls or stone circles indicating "the distance between two modes of being, the profane and the religious" 27 and limiting the central space of a special quality enclosed within. Paripur's five characters have challenged the restrictions put on them in their everyday life, abandoned their lives and in their search for freedom they arrive at the garden in Karaj. To get there is a real ordeal - the women have to face the dangers of the outside world to which they are unaccustomed and bear what one of them euphemistically calls the "bitter experience of travelling", ${ }^{28}$ here meaning male violence. Finally a reward awaits them all when they find a place where they can take care of themselves on their own and - as one of them says - "get rid of the men who control us". ${ }^{29}$ In the garden they feel safe inside their small enclave where they do whatever they wish - work, create art or break away from their expected social roles without being accused of madness.

Perhaps the most important element of the garden in Karaj is a girl who turned into a tree. In even the most elementary concepts of the sacred cosmic centre, there is always a sacred tree, due to its periodical renewal symbolising the cosmos with its endless regeneration. ${ }^{30}$ For Parsipur's character, transforming into tree is a way to escape from society. The girl's family considers her mad, but they cannot remove her from the ground, so finally her brother decides to get rid of the garden altogether - the good name of family becomes more important than any close feelings towards the girl. When the women turn their garden into a small, feminine utopia, the tree blooms and later on its seeds are cast around the area, carried by wind and water.

24 W.L. Hanaway, Baḡ: iii. In Persian Literature, [in:] Encyclopaedia Iranica, vol. 3, ed. E. Yarshater, London-New York 1989, p. 395.

25 S. Parsipur, Women without Men: A Novella, Syracuse 1998, p. 101.

26 W.L. Hanaway, op. cit., p 396.

27 M. Eliade, The Sacred and the Profane: The Nature of Religion, New York 1959, p. 25.

28 S. Parsipur, op. cit., p. 97.

29 Ibidem, p. 78.

30 M. Eliade, op. cit., p. 148. 
In Iranian mythology, trees and other plants are endowed with a soul. It was believed that a tree may be an oracle, as the one that predicted the fate of Alexander the Great. Animistic beliefs have survived in Iran until today taking the form of some trees being assigned Shi'a saints who can perform miracles or fulfil people's wishes through their trees. ${ }^{31}$ In the Middle-Persian text Bundahishn, there is a tree that grows in the middle of the mythical ocean and has multiple types of seeds that spawn various plants (18:9). ${ }^{32}$ The regeneration of the tree repeats every year when the bird Simorq mixes the seeds with water, which afterwards fall down together with the rain on the ground in all directions $(27: 3){ }^{33}$

I believe that, in the context of the Parsipur's novel, both aspects of a tree's symbolism are equally important - the tree as a symbol of life and inexhaustible fertility, as well as the tree constituting the centre of the world. The one symbolizing life and fertility is often identified with the tree of life, which is the source of immortality. It is related to the image of a great goddess. By her presence, the girl-tree in Women without Men does not only legitimize the sacredness of the garden, but also brings to mind the image of goddess of fertility and motherhood. In the real world, the girl has refused to be a mere sexual object for men, yet she is sensitive to the suffering of children and does not reject femininity itself - only its understanding imposed by the norms and cultural context of a male-dominated society. Once transformed into a tree she manages to break free from the imposed social patterns and limitations, becoming the Mother and giving new life by flourishing and generating seeds. When she turns to seed, her life ends but she is also reborn in the form of a number of new plants:

"The tree had turned completely into seeds. A mountain of seeds. A strong wind blew the seeds of Mahdokht into the water. Mahdokht travelled with the water. She travelled all over the world." 34

This directly recalls to mind the Iranian myth telling the story of the creation of plants. At the dawn of history, Ameretat - a deity watching over the world of plants - crumbled plants and mixed them up with the rain water which were then cast down upon the whole earth by another deity - Tishtrya:

"Ten thousand of them grew forth of one special description, for keeping away the ten thousand species of disease which the evil spirit produced for the creatures; and from those ten thousand, the 100,000 species of plants have grown forth." $(9: 4)^{35}$

Parsipur's works, like Women without Men, are deeply immersed in the context of Iranian culture, but at the same time attractive to readers all over the world not only as a document of life in Iran. Through such means of expression as magical realism and usage of universal, widely understandable symbols they cross national borders and are successfully translated and sold in a variety of countries - the

${ }^{31}$ Cf. H. A lam, Derakt, [in:] Encyclopaedia Iranica, vol. 7, ed. E. Yarshater, New York 2002, p. $316-319$.

${ }^{32}$ The Bundahishn, transl. E.W. West, [in:] Sacred Books of the East: Volume 5: Pahlavi Texts, Oxford 1880 [reprint Delhi 2003], p. 66.

${ }^{33}$ Ibidem, p. 100,

${ }^{34}$ S. Parsipur, op. cit., p. 122.

35 The Bundahishn, p. 31. 
symbols of Paradise garden or the wall-surrounded sanctuary are not exclusively Iranian or Islamic, but also accessible to readers raised in other cultural contexts.

\section{Women without Men - A Movie in the Search for Freedom}

Inspiration from the works of Parsipur is found in the oeuvre of Shirin Neshat (b. 1957), an Iranian visual artist who has gained international fame due to her individual style of photographs, films and video installations, which for years have tackled the subject of the boundaries in the Iranian and Muslim culture - between man and woman, the sacred and the profane, reality and magical realism. Neshat left Iran at the age of seventeen to embark on her artistic education in the United States of America and then returned to her homeland in 1990, and her encounter with Iran - entirely transformed after the Islamic Revolution and devastated by the war with Iraq - was a turning point in her artistic career. Under this influence she created a series of her most famous photographic works entitled Women of Allah (Zanan-e Allah, 1993-1997), which have resonated widely in the West and inspired others, contributing to contemporary discussions regarding the decolonization of global culture and the image of the Orient. Her photographs of herself in a chador carrying weapons, illuminated with Persian calligraphy, challenged the separation of the two spheres - the private attributed to women, and the public attributed to men - by mixing the coexistence of femininity and violence, and the paradoxes and conflicts in the culture of the Middle East. ${ }^{36}$

Neshat's works bear the stigma of living in exile - the loss of one's cultural homeland and construction of a multidimensional identity create a specific point of view. However, Neshat manages to create works that are not disengaged from their roots, but at the same time constitute not only a purely ethnographic message, but explore universally human themes, understandable to a wide audience: "Although she explicitly brings out culturally specific phenomena in her work, she simultaneously succeeds in subtly striking the tenor of a more universal language; not only does she present a nuanced image of her country of origin but also delivers a revealing insight into 'Western' modes of perception." ${ }^{37}$

At the same time there is also a deeper interpretative level of her works, not necessarily understandable for the Western audience unable to read Persian women's poems calligraphed on her works. As Scheiwiller emphasises, "the actual reading of the inscriptions by Iranian women writers reveals other in-depth interpretations of these photographs, such as resistance and empowerment. [...] she employs the texts of these women to add to the plurality of voices of Iranian women [...]. For instance, Neshat inscribes the poetry of Saffarzadeh, thus giving her photographs another twist in their meanings in relation to the body as a sacred site." ${ }^{\prime 38}$

${ }^{36}$ B. Schmitz, Shirin Neshat, Nafas Art Magazine, http://u-in-u.com/en/nafas/articles/2005/neshat (access: 15.12.2016).

${ }^{37}$ Ibidem.

${ }^{38}$ S.G. Scheiwiller, In the House of Fatemeh: Revisiting Shirin Neshat's Photographic Series Women of Allah, [in:] Performing the Iranian State: Visual Culture and Representations of Iranian Identity, ed. S.G. Scheiwiller, London 2013, p. 211. 
One of Neshat's works are video sequences created for the film Women without Men, based on the novel by Parsipur, where the black-and-white dualism characteristic for many of her previous works was abandoned in favour of a magical realism style. Later on she directed a feature film, released in 2009, described by her collaborator Shoja Azari as a "study in the anatomy of patriarchy of the Iranian society". ${ }^{39}$ As the artist herself says, she decided to make the movie based on a book, "because it at once was addressing the question of being a female - traditionally, historically in Iran - and the question of four women who are all looking for an idea of change, freedom and democracy - while the country of Iran, equally, as if another character, also struggled for an idea of freedom and democracy and independence from the foreign interventions." 40

The film places more emphasis on the political events in Iran during the 1950s than the book. It is critical of the CIA coup that brought down the Mosaddeq's government, replacing it with the pro-American Shah's regime: "The return to the decisive point in Iranian history, the coup of 1953, is a return to a proper reexamination of the ensuing events, leading ultimately to the Islamic Republic which emerged out of the revolution that brought down the Shah's regime."41 The desire of women to liberate themselves from the restrictions of traditional culture runs parallel with their efforts to change the political situation in the country. The movie is dedicated to all those who fought for freedom in Iran and in this sense it departs from a women-centred discourse and shows how bitter history can repeat itself.

\section{Conclusions}

After the Islamic Revolution of 1979, Iranian women writers with their feminist issues successfully stepped into mainstream literary discourse, focusing on topics previously omitted, emphasising socio-cultural gender issues and contributing to the development of specific attitudes and values among readers. They became visible through their books and articles, crossing the boundaries set by class structure, tradition or religion; this also concerns those who write in exile. Women write about their limitations and suffering that are no longer perceived as unavoidable and challenge androcentric ideology, restrictive law and the traditional perception of gender relations. By using a special style, metaphors or artistic tricks they disclosure topics hitherto hidden, unspoken and relegated to the sphere of private problems.

Iranian female artists engaged in the struggle for women's issues with many obstacles but some, like Shahrnush Parsipur, became a successful writer reaching a wide audience, even thongh she spent time in prison, suffered mental issues and then her only option was to leave her homeland. Her courageous literary works,

${ }^{39}$ H. Bresheeth, Shirin Neshat's Women Without Men, "Third Text" 2010, 24(6), p. 755.

${ }^{40} \mathrm{~S}$. Neshat, Art in Exile, TED, http://www.ted.com/talks/shirin_neshat_art_in_exile?language=en (access: 23.12.2016).

${ }^{41}$ H. Bresheeth, op. cit., p. 755. 
like the short novel Woman without Men described here, helped to shape feminist discourse in the country, and inspired future generations of writers and other artists, contributing to the fact that women's issues have gained a new meaning in contemporary Iran. Through their works, female authors are advocates of change in the Iranian society shaped by the male-dominated culture: "Women are raising their voices, telling their tales." ${ }^{22}$ Most importantly, their efforts do not remain suspended in a vacuum but reach masses of readers and shape their feminist consciousness and values.

\section{Bibliography}

A 'lam H., Derakt, [in:] Encyclopaedia Iranica, vol. 7, ed. E. Yarshater, New York 2002, pp. 316-319.

Afary J., Sexual Politics in Modern Iran, Cambridge-New York 2009.

Bazin M., Bağ: ii. General, [in:] Encyclopaedia Iranica, vol. 3, ed. E. Yarshater, London-New York 1989, pp. 393-395.

Bresheeth H., Shirin Neshat's Women Without Men, "Third Text" 2010, no. 24(6), pp. 754-758.

Doniya-ye zan: Dar goft-o-gu ba allame-ye Seyyed Mohammad Hoseyn Fazlallah, Tehran 1383/2004.

Eliade M., The Sacred and the Profane: The Nature of Religion, New York 1959.

Haeri S., Law of Desire: Temporary Marriage in Shi'i Iran, Syracuse 2014.

Hanaway W.L., Bāğ: iii. In Persian Literature, [in:] Encyclopaedia Iranica, vol. 3, ed. E. Yarshater, London-New York 1989, pp. 395-396.

Keddie N.R., Modern Iran: Roots and Results of Revolution, New Haven 2006.

Krasnowolska A., Postowie, [in:] S. Parsipur, Tuba i znaczenie nocy, Kraków 2012, pp. 427-436.

Lewis F., Yazdanfar F., Introduction: Iranian Women, the Short Story and the Revolution 1979, [in:] In a Voice of Their Own: A Collection of Stories by Iranian Women Written since the Revolution of 1979, eds. F. Lewis, F. Yazdanfar, Costa Mesa 1996, pp. ix-Xxxvii.

Milani F., Veils and Words: The Emerging Voices of Iranian Women Writers, Syracuse 1992.

Milani F., Gender Relations: i. In Modern Persia, [in:] Encyclopaedia Iranica, vol. 10, ed. E. Yarshater, New York 2001, pp. 405-411.

Mobasser N., Introduction, [in:] S. Rahbaran, Iranian Writers Uncensored: Freedom, Democracy, and the Word in Contemporary Iran, Champaign 2012, pp. v-xxvi.

Neshat S., Art in Exile, TED, http://www.ted.com/talks/shirin_neshat_art_in exile?language $=$ en (access: 23.12.2016).

Parsipur S., Women without Men: A Novella, Syracuse 1998.

Ruthven M., Islam: A Very Short Introduction, New York 2012.

Scheiwiller S.G., In the House of Fatemeh: Revisiting Shirin Neshat's Photographic Series Women of Allah, [in:] Performing the Iranian State: Visual Culture and Representations of Iranian Identity, ed. S.G. Scheiwiller, London 2013, pp. 201-220.

${ }^{42}$ F. Milani, Veils and Words: The Emerging Voices of Iranian Women Writers, Syracuse 1992, p. 234. 
Schmitz B., Shirin Neshat, Nafas Art Magazine, http://u-in-u.com/en/nafas/articles/2005/neshat/ (accessed: 15.12.2016).

Sheibani K., Without Men: Parsipur's Polyphonic Novel, Iranian.com, http://iranian. com/Books/2003/September/KS/index.html (access: 12.12.2016).

Talattof K., Iranian Women's Literature: From Pre-Revolutionary Social Discourse to Post-Revolutionary Feminism, "International Journal of Middle East Studies" 1997, no. 29(4), pp. 531-558.

Talattof K., The Politics of Writing in Iran: A History of Modern Persian Literature, Syracuse 2000.

The Bundahishn, transl. E.W. West, [in:] Sacred Books of the East: Volume 5: Pahlavi Texts, Oxford 1880 [reprint Delhi 2003], pp. 3-151.

Yahaqqi M.J., Farhang-e asatir va dastan-vareha dar adabiyat-e farsi, Tehran $1386 / 2007$. 